\section{FRI0509 SAFETY AND EFFICACY OF TOFACITINIB, AN ORAL JANUS KINASE INHIBITOR, UP TO 24 MONTHS IN PATIENTS WITH ACTIVE PSORIATIC ARTHRITIS: INTERIM DATA FROM OPAL BALANCE, AN OPEN-LABEL, LONG-TERM EXTENSION STUDY}

P. Nash ${ }^{1}$, L.C. Coates ${ }^{2}$, A.J. Kivitz ${ }^{3}$, P.J. Mease ${ }^{4}$, D.D. Gladman ${ }^{5}$,

J.A. Covarrubias-Cobos ${ }^{6}$, D. Fleishaker ${ }^{7}$, C. Wang ${ }^{7}$, E. Kudlacz ${ }^{7}$, S. Menon ${ }^{7}$, T. Hendrikx ${ }^{8}$, K.S. Kanik ${ }^{7} .{ }^{1}$ Department of Medicine, University of Queensland, St Lucia, Brisbane, Australia; ${ }^{2}$ Leeds Institute of Rheumatic and Musculoskeletal Medicine, University of Leeds, Leeds, United Kingdom; ${ }^{3}$ Department of Rheumatology, Altoona Center for Clinical Research, Duncansville, PA; ${ }^{4}$ Swedish Medical Center and University of Washington, Seattle, WA, United States; ${ }^{5}$ Department of Medicine, University of Toronto, Toronto Western Hospital, Toronto, ON, Canada: ${ }^{6}$ Unidad Reumatologica Las Americas S.C.P. Mérida, Yucatán, Mexico; ${ }^{7}$ Pfizer Inc, Groton, CT; ${ }^{8}$ Pfizer Inc, Collegeville, PA, United States

Background: Tofacitinib is an oral Janus kinase inhibitor under investigation for psoriatic arthritis (PsA). Interim data (database not locked) from $\leq 24$ months' participation (3 years' total treatment duration) for patients (pts) with active PsA in an ongoing, open-label, long-term extension study (LTE; NCT01976364 OPAL Balance) is reported.

Objectives: To evaluate the safety, tolerability and efficacy of tofacitinib in pts with active PsA.

Methods: Eligible pts from 2 pivotal Phase 3 tofacitinib PsA studies (NCT01877668 OPAL Broaden, NCT01882439 OPAL Beyond) could enter a 3-year LTE $\leq 3$ months after completing the qualifying study or discontinuing for non study-drug-related reasons. Pts were to receive tofacitinib $5 \mathrm{mg}$ twice daily (BID) for 1 month, after which an increase to $10 \mathrm{mg}$ BID or reduction back to 5 $\mathrm{mg}$ BID was permitted at any time for efficacy or safety reasons. Concomitant treatment with a single conventional synthetic disease-modifying antirheumatic drug (csDMARD) was allowed but not required. Primary endpoints were incidence and severity of adverse events (AEs) and change from baseline in laboratory values. Efficacy was a secondary endpoint.

Results: 680/685 enrolled pts were treated. 608 (89.4\%) remained at data cut-off. Mean (range) duration of tofacitinib exposure in this LTE was 206 (3-741) days. $661(97.2 \%)$ pts took a csDMARD on Day 1, and $73(11.0 \%)$ later discontinued csDMARD. To Month 24, 860 AEs were reported in $367(54.0 \%)$ pts, $41(6.0 \%)$ pts had serious AEs and $24(3.5 \%)$ pts discontinued due to AEs. Special interest AEs included 6 serious infections $(0.9 \%), 10$ herpes zoster events (1.5\%) including 1 serious event, 2 major adverse cardiovascular events $(0.3 \%)$ and 2 malignancies $(0.3 \%)$. There were 3 deaths (not attributed to treatment, as assessed by the investigator) due to metastatic pancreatic carcinoma, acute cardiac failure and pulmonary embolism. No Gl perforation, inflammatory bowel disease or uveitis cases were reported. One AE of latent TB was reported. One pt met discontinuation criteria for laboratory values due to increased serum creatinine $>50 \%$ and $>0.5 \mathrm{mg} / \mathrm{dL}$ over the average of screening and baseline creatinine. Small mean decreases in absolute lymphocyte and neutrophil counts, and small mean increases in serum lipid markers, were observed; 18 (2.6\%) pts started new lipid-lowering medication during the LTE (80 [11.8\%] pts were on lipid-lowering drug at baseline). Efficacy was maintained in the LTE (Table 1).

Table 1. Summary of efficacy through to Month $15^{2}$

\begin{tabular}{|c|c|c|c|c|c|}
\hline & \multicolumn{5}{|c|}{$\begin{array}{c}\text { Tofacitinib (all patients) } \\
\qquad(\mathrm{N}=680)\end{array}$} \\
\hline & Month 3 & Month 6 & Month 9 & Month 12 & Month 15 \\
\hline ACR20, $\mathrm{n} N 1(\%)$ & $421 / 606(69.5)$ & $326 / 470(69.4)$ & $219 / 307(71.3)$ & $109 / 154(70.8)$ & $48 / 66(72.7)$ \\
\hline ACR50, n/N1 (\%) & $264 / 607(43.5)$ & $217 / 469(46.3)$ & $160 / 308(52.0)$ & $77 / 153(50.3)$ & $31 / 66(47.0)$ \\
\hline ACR70, n/N1 (\%) & $154 / 608(25.3)$ & $140 / 471(29.7)$ & $92 / 308$ (29.9) & $48 / 153(31.4)$ & $19 / 67(28.4)$ \\
\hline$\triangle \mathrm{HAQ}-\mathrm{DI}, \operatorname{mean}(\mathrm{SD})[\mathrm{N} 1]$ & $-0.5(0.6)[606]$ & $-0.5(0.6)[472]$ & $-0.5(0.6)[308]$ & $-0.5(0.6)[154]$ & $-0.5(0.6)[67]$ \\
\hline $\begin{array}{l}\text { PASI75 response rate, } \\
\mathrm{n} \mathrm{N} 1(\%)^{\mathrm{b}}\end{array}$ & $219 / 387(56.0)$ & $180 / 304(59.2)$ & $113 / 202(55.9)$ & $55 / 100(55.0)$ & $31 / 45(68.9)$ \\
\hline$\Delta \mathrm{LEI}$, mean $(\mathrm{SD})^{\mathrm{c}}[\mathrm{N} 1]$ & $-1.6(1.8)[399]$ & $-1.5(1.8)[312]$ & $-1.6(1.8)[204]$ & $-1.4(2.0)[102]$ & $-1.8(2.1)[48]$ \\
\hline$\Delta \mathrm{DSS}$, mean $(\mathrm{SD})^{\mathrm{c}}[\mathrm{N} 1]$ & $-6.9(7.8)[330]$ & $-6.8(8.3)[254]$ & $-6.9(7.2)[164]$ & $-6.9(6.6)[83]$ & $-7.3(7.4)[39]$ \\
\hline$\Delta$ Pain, mean $(S D)^{d}[N 1]$ & $-25.3(26.8)[604]$ & $-26.3(28.0)[471]$ & $-28.7(28.9)[308]$ & $-28.7(29.2)[154]$ & $-31.4(29.1)[67$ \\
\hline
\end{tabular}

\section{Baseline values represent those at the start of the qualifying study}

Only evaluable pts at a visit of interest were included in the analysis and missing values were not imputed

"Efficacy data is reported to Month 15 as sample sizes were too small beyond this time point, ${ }^{b}$ Among patients with baseline BSA

$\geq 3 \%$ and PASI $>0$; 'Among patients with baseline score $>0$; ${ }^{\text {APatient's }}$ assessment of arthritis pain measured using VAS (mm)

$\Delta$, change from baseline; ACR, American College of Rheumatology, ACR2 $20 / 50 / 70$, ACR $20 \% / 50 \% / 70 \%$ response rate; BSA body surface area; DSS, Dactylitis Severity Score; HAQ-DI, Health Assessment Questionnaire Disability Index; LEI, Leeds Enthesitis Index; $\mathrm{N}$, number of patients in full analysis set; $\mathrm{N} 1$, number of evaluable patients at a visit; $\mathrm{n}$, number of responders; PASI75, Psoriasis Area Severity Index 75\% improvement; PsA, psoriatic arthritis; SD, standard deviation; VAS, visual analogue scale

Conclusions: Over 24 months in the LTE, the safety profile of tofacitinib in pts with active PsA was generally similar to that of the pivotal Phase 3 studies. No new safety signals were identified. Efficacy was maintained over time.
Acknowledgements: To be presented at AAD 2017 and reproduced with permission. This study was sponsored by Pfizer Inc. Editorial support was provided by S Morgan of CMC and was funded by Pfizer Inc.

Disclosure of Interest: P. Nash Grant/research support from: AbbVie, Amgen, Bristol-Myers Squibb, Celgene, Janssen, Eli Lilly, Novartis, Pfizer Inc, Roche, UCB, Consultant for: AbbVie, Amgen, Bristol-Myers Squibb, Celgene, Janssen, Eli Lilly, Merck, Novartis, Pfizer Inc, Sanofi, Roche, UCB, Speakers bureau: AbbVie, Amgen, Bristol-Myers Squibb, Celgene, Janssen, Novartis, Pfizer Inc Roche, UCB, L. Coates Speakers bureau: Pfizer Inc, A. Kivitz Grant/research support from: AbbVie, Amgen, Bristol-Myers Squibb, Genentech, Pfizer Inc Consultant for: AbbVie, Amgen, Bristol-Myers Squibb, Genentech, Pfizer Inc, Speakers bureau: AbbVie, Amgen, Bristol-Myers Squibb, Genentech, Pfizer Inc P. Mease Grant/research support from: AbbVie, Amgen, Bristol-Myers Squibb, Celgene, Janssen, Eli Lilly, Novartis, Pfizer Inc, Sun, UCB, Consultant for: AbbVie, Amgen, Bristol-Myers Squibb, Celgene, Crescendo, Corrona, Dermira, Janssen, Eli Lilly, Merck, Novartis, Pfizer Inc, Sun, UCB, Zynerba, Speakers bureau: AbbVie, Amgen, Bristol-Myers Squibb, Celgene, Crescendo, Genetech, Janssen, Novartis, Pfizer Inc, UCB, D. Gladman Grant/research support from: Amgen, AbbVie, Bristol-Myers Squibb, Celgene, Janssen, Eli Lilly, Pfizer Inc, Novartis, UCB, Consultant for: Amgen, AbbVie, Bristol-Myers Squibb, Celgene, Janssen, Eli Lilly, Pfizer Inc, Novartis, UCB, Speakers bureau: Amgen, AbbVie, Bristol-Myers Squibb, Celgene, Janssen, Eli Lilly, Pfizer Inc, Novartis, UCB, J. Covarrubias-Cobos Grant/research support from: Bristol-Myers Squibb, Eli Lilly, Janssen, Pfizer Inc, D. Fleishaker Shareholder of: Pfizer Inc, Employee of: Pfizer Inc, C. Wang Shareholder of: Pfizer Inc, Employee of: Pfizer Inc, E. Kudlacz Shareholder of: Pfizer Inc, Employee of: Pfizer Inc, S. Menon Shareholder of: Pfizer Inc, Employee of: Pfizer Inc, T. Hendrikx Shareholder of: Pfizer Inc, Employee of: Pfizer Inc, K. Kanik Shareholder of: Pfizer Inc, Employee of: Pfizer Inc

DOI: 10.1136/annrheumdis-2017-eular.1414

\section{FRI0510 CORRELATION OF THE ROUTINE ASSESSMENT OF PATIENT INDEX DATA (RAPID-3) WITH OTHER PSORIATIC ARTHRITIS COMPOSITE DISEASE ACTIVITY MEASURES IN PATIENTS RECEIVING ADALIMUMAB}

P.J. Mease ${ }^{1}$, S. Chen ${ }^{2}$, F. Ganz ${ }^{3}$, W. Tillett ${ }^{4} .{ }^{1}$ Swedish Medical Center and University of Washington, Seattle; ${ }^{2}$ AbbVie, Inc., North Chicago, United States; ${ }^{3}$ AbbVie, Inc., Baar, Switzerland; ${ }^{4}$ Royal United Hospitals Bath NHS Foundation Trust, Bath, United Kingdom

Background: There is increased interest across rheumatologic disease to utilize patient (pt)-reported outcomes (PROs) in disease assessment. Several measures entirely derived from PROs, such as the 3-component routine assessment of pt index data (RAPID-3), have been shown to be closely correlated with physician rheumatoid arthritis assessments using traditional composite scores. ${ }^{1}$

Objectives: To assess the correlation between the RAPID-3 and other psoriatic arthritis (PsA) composite indices [eg, disease activity index for PsA (DAPSA), minimal disease activity (MDA)] in pts with PsA receiving adalimumab (ADA) or placebo (PBO).

Methods: This post hoc analysis used data from the ADEPT trial, which included pts with active PsA despite prior DMARD therapy who were randomized to receive ADA or PBO for 24 weeks (wks). Mean RAPID-3 was summarized by visit for each treatment group. Correlations between RAPID-3 and DAPSA over time were assessed through Pearson and Spearman coefficient. Pts were categorized at wk 24 according to DAPSA [Remission: $\leq 4$; low disease activity (LowDA): $>4-\leq 14$; moderate disease activity (ModDA): $>14-\leq 28$; high disease activity (HighDA): $>28$ ) and MDA [achievement of 5 of 7 or the more stringent 7 of 7 criteria (very low disease activity [VLDA]): yes, no], and assessed for the numbers of pts in each respective RAPID-3 disease activity state (Remission: $\leq 3$; LowDA: $>3-\leq 6$; ModDA: $>6-\leq 12$; HighDA: $>12)$. The Kappa statistic was used to describe the agreement between the numbers of pts in respective disease activity categories by RAPID-3, DAPSA, and MDA. Data were as observed.

Results: Amongst the 151 and 162 pts randomized to receive ADA and PBO, respectively, both groups exhibited HighDA when assessed by RAPID-3 [13.1 for both groups; 55\% (ADA) and 54\% (PBO) in HighDA]. At wk 24, mean RAPID-3 remained in HighDA for the PBO group (12.6), whereas it decreased to a state of LowDA (6.8) in those receiving ADA. Following 24 wks of treatment, $39 \%$ and $24 \%$ in the ADA group were in remission by RAPID-3 and DAPSA, respectively. Fewer pts in the $\mathrm{PBO}$ group were in remission by either definition at wk 24 ( $8 \%$ and $3 \%$, respectively). At baseline, there was moderate correlation between RAPID-3 and DAPSA in both treatment groups (ADA: 0.512; PBO: 0.510). At wk 24, the correlations in both treatment groups increased, with the correlation observed in the ADA group outpacing the PBO group (ADA: 0.721; PBO: 0.590). Similarly, disease activity categorizations by RAPID-3 correlated with DAPSA and MDA categorizations (Table).

Conclusions: In a PBO-controlled trial of ADA in pts with PsA, there was good correlation between disease activity captured by pt's self-assessment, via the RAPID-3, and physician assessment, underscoring the potential utility of pt-derived measures in assessing disease activity.

References:

[1] Pincus and Sokka. Best Pract Res Clin Rheumatol 2007;21(4):733-53. Acknowledgements: AbbVie: study (NCT00646386) sponsor, contributed to 


\begin{tabular}{|c|c|c|c|c|c|c|}
\hline \multirow{2}{*}{\multicolumn{2}{|c|}{$\begin{array}{l}\text { Disease Activity } \\
\text { Assessment }\end{array}$}} & \multicolumn{4}{|c|}{ RAPID-3 } & \multirow[b]{2}{*}{ Kappa } \\
\hline & & $\begin{array}{c}\text { Remission } \\
\leq 3\end{array}$ & $\begin{array}{l}\text { LOWDA } \\
>3-\leq 6\end{array}$ & $\begin{array}{l}\text { ModDA } \\
>6-\leq 12\end{array}$ & $\begin{array}{c}\text { HighDA } \\
>12\end{array}$ & \\
\hline \multicolumn{7}{|c|}{ DAPSA } \\
\hline 疎 & $\begin{array}{l}\text { Remission } \\
\text { LowDA } \\
\text { ModDA } \\
\text { HighDA }\end{array}$ & $\begin{array}{c}29(20.9) \\
15(10.8) \\
6(4.3) \\
4(2.9)\end{array}$ & $\begin{array}{l}3(2.2) \\
11(7.9) \\
8(5.8) \\
4(2.9)\end{array}$ & $\begin{array}{c}1(0.7) \\
6(4.3) \\
17(12.2) \\
12(8.6)\end{array}$ & $\begin{array}{c}0 \\
1(0.7) \\
4(2.9) \\
18(12.9)\end{array}$ & $\begin{array}{l}0.388^{\prime \prime} \\
0.572^{b}\end{array}$ \\
\hline $\begin{array}{l}\frac{8}{8} \\
\frac{\pi}{a}\end{array}$ & $\begin{array}{l}\text { Remission } \\
\text { LowDA } \\
\text { ModDA } \\
\text { HighDA }\end{array}$ & $\begin{array}{l}4(2.8) \\
5(3.4) \\
1(0.7) \\
1(0.7)\end{array}$ & $\begin{array}{c}0 \\
3(2.1) \\
7(4.8) \\
4(2.8)\end{array}$ & $\begin{array}{c}0 \\
5(3.4) \\
16(11) \\
29(20)\end{array}$ & $\begin{array}{c}0 \\
1(0.7) \\
9(6.2) \\
60(41.4)\end{array}$ & $\begin{array}{l}0.284^{2} \\
0.484^{b}\end{array}$ \\
\hline \multicolumn{7}{|c|}{ Minimal Disease Activity } \\
\hline 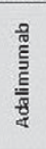 & $\begin{array}{c}\text { MDA } \\
\text { Yes } \\
\text { No } \\
\text { VLDA } \\
\text { Yes } \\
\text { No }\end{array}$ & $\begin{array}{c}45(32.1) \\
9(6.4) \\
11(15.3) \\
17(23.6)\end{array}$ & $\begin{array}{c}5(3.6) \\
21(15) \\
0 \\
12(16.7)\end{array}$ & $\begin{array}{c}1(0.7) \\
36(25.7) \\
0 \\
17(23.6)\end{array}$ & $\begin{array}{c}0 \\
23\{16.4\} \\
0 \\
15\{20.8\}\end{array}$ & $0.574^{c}$ \\
\hline $\begin{array}{l}\frac{8}{0} \\
\frac{\pi}{2}\end{array}$ & $\begin{array}{c}\text { MDA } \\
\text { Yes } \\
\text { No } \\
\text { VLDA } \\
\text { Yes } \\
\text { No }\end{array}$ & $\begin{array}{l}7(4.8) \\
4(2.8) \\
\\
1(1.4) \\
7(10.1)\end{array}$ & $\begin{array}{c}0 \\
14(9.7) \\
0 \\
0 \\
5(7.2)\end{array}$ & $\begin{array}{c}0 \\
50(34.5) \\
0 \\
17(24.6)\end{array}$ & $\begin{array}{c}0 \\
70(48.3) \\
0 \\
39(56.5)\end{array}$ & $0.119^{c}$ \\
\hline $\begin{array}{l}\text { All val } \\
\text { 'Kapp } \\
\text { DAPSA } \\
\text { "Kapp } \\
\text { activit } \\
\text { 'Kapp } \\
\text { activit } \\
\text { activit } \\
\text { DAPA } \\
\text { Minim } \\
\text { enthes } \\
\text { RAPID } \\
\text { minim } \\
\text { activit }\end{array}$ & $\begin{array}{l}\text { are } n(\%) \text {, unle } \\
\text { reem ent betw } \\
\text { reement betw } \\
\text { teg ories of the } \\
\text { reement betw } \\
\text { teg ories of the } \\
\text { sease activitys } \\
\text { lise ase activity } \\
\text { points } \leq 1 \\
\text { routine assessn } \\
\text { lise ase activity, } \\
\text { LDA, very low }\end{array}$ & $\begin{array}{l}\text { wise indicatec } \\
\text { numbers of } p= \\
\text { numbers of } p a \\
\text { and the DAP } \\
\text { umbers of } p a \\
\text { and achiever } \\
\text { mission, } \leq 4 ; \text {;o } \\
T J C \leq 1 \text {, SJC } \leq 1 \\
\text { atient index } \\
\text { low dise ase a } \\
\text { tivity. }\end{array}$ & $\begin{array}{l}\text { ts across the } \\
\text { ts in the ren } \\
\text { ts in the ren } \\
t \text { (yes/no) of } \\
\text { A, S14; Mod } \\
\text { SI S1; patier } \\
\text { DAPSA, dis } \\
\text { ty, ModDA, }\end{array}$ & $\begin{array}{l}\text { ease activity } \\
\text { on + LowDA } \\
\text { on + LowDA } \\
\text { MDA) or } 7 \text { of } \\
\leq 28 \text {; HighDA } \\
\text { in } \leq 15 \text {; patie } \\
\text { activity inde }\end{array}$ & $\begin{array}{l}\text { ModDA + Hi } \\
\text { ModDA + Hit } \\
\text { LDA) criteria } \\
8 . \\
\text { lobal } \leq 20 ; H A \\
\text { psoriatic art }\end{array}$ & $\begin{array}{l}\text { - } 3 \text { and the } \\
\text { ise ase } \\
\text { isease } \\
\text { imal disease } \\
0.5 \text {; tender } \\
\text { MDA, } \\
\text { dise ase }\end{array}$ \\
\hline
\end{tabular}

design, data collection, analysis, interpretation, and abstract writing, review, and approval. Medical writing: Ben Wolfe of AbbVie.

Disclosure of Interest: P. Mease Grant/research support from: AbbVie, Amgen, Bristol Myers, Celgene, Genentech, Janssen, Lilly, Merck, Novartis, Pfizer, Sun Pharma, and UCB, Consultant for: AbbVie, Amgen, Bristol Myers, Celgene, Genentech, Janssen, Lilly, Merck, Novartis, Pfizer, Sun Pharma, and UCB, Speakers bureau: AbbVie, Amgen, Bristol Myers, Celgene, Genentech, Janssen, Lilly, Merck, Novartis, Pfizer, Sun Pharma, and UCB, S. Chen Shareholder of: AbbVie, Inc., Employee of: AbbVie, Inc., F. Ganz Shareholder of: AbbVie, Inc., Employee of: AbbVie, Inc., W. Tillett Grant/research support from: AbbVie, Celgene, Novartis, Pfizer, and UCB, Consultant for: AbbVie, Celgene, Novartis, Pfizer, and UCB, Speakers bureau: AbbVie, Celgene, Novartis, Pfizer, and UCB DOI: 10.1136/annrheumdis-2017-eular.1952

\section{FRI0511 SECUKINUMAB DEMONSTRATES CONSISTENT SAFETY OVER LONG-TERM EXPOSURE IN PATIENTS WITH PSORIATIC ARTHRITIS AND MODERATE-TO-SEVERE PLAQUE PSORIASIS: UPDATED POOLED SAFETY ANALYSES}

P.J. Mease ${ }^{1}$, I.B. Mclnnes ${ }^{2}$, K. Reich ${ }^{3}$, P. Nash ${ }^{4}$, M. Andersson ${ }^{5}$, K. Abrams ${ }^{6}$, L. Pricorp ${ }^{6}$, T. Fox ${ }^{5} .{ }^{1}$ Swedish Medical Center and University of Washington, Seattle, United States; ${ }^{2}$ University of Glasgow, Glasgow, United Kingdom; ${ }^{3}$ Dermatologikum Hamburg and Georg-August-University Göttingen, Hamburg, Germany; ${ }^{4}$ University of Queensland, St Lucia, Australia; ${ }^{5}$ Novartis Pharma AG, Basel, Switzerland; ${ }^{6}$ Novartis Pharmaceuticals Corp., East Hanover, United States

Background: Pooled safety data from secukinumab psoriasis ( $\mathrm{PsO}$ ) and psoriatic arthritis (PsA) clinical trial programs after $\sim 1$ year of exposure have been reported. ${ }^{1,2}$

Objectives: To report updated longer-term secukinumab exposure safety data from PsO and PsA studies (data cut-off: 25 June 2016).

Methods: The PsO data pool consisted of 9 Phase III studies in moderate-tosevere plaque PsO and PsA pool consisted of 3 Phase III studies in active PsA. Secukinumab doses differed in the studies and included intravenous (up to 10 $\mathrm{mg} / \mathrm{kg}$ ) or subcutaneous (s.c.; 75-300 mg) loading, followed by s.c. maintenance dosing (300, 150 or $75 \mathrm{mg}$ ). Placebo patients were re-randomised to secukinumab at 12-24 weeks depending on study design. Only data for approved secukinumab 300 and $150 \mathrm{mg}$ doses were included in analysis. Exposure adjusted incident rates (EAIR) were used to adjust for differences in exposure.

Results: In both PsO and PsA, the most frequently reported adverse events (AEs) with secukinumab were non-serious infections of the upper respiratory tract, headache and arthralgia (Table). The EAIRs of AEs of special interest with secukinumab including Crohn's disease, Candida infections, serious infections, inflammatory bowel disease, major adverse cardiac events and neutropenia (reported in the Table) were similar in both PSO and PsA indications, and comparable to those reported previously. ${ }^{1,2}$ No cases of tuberculosis (new onset or reactivation) were reported.
Table 1. Summary of pooled safety of secukinumab in PSO and PsA

\begin{tabular}{lcc}
\hline & $\begin{array}{c}\text { PSO } \\
\text { Any secukinumab } \\
\mathrm{N}=3893\end{array}$ & $\begin{array}{c}\text { PsA } \\
\text { Any secukinumab } \\
\mathrm{N}=1128\end{array}$ \\
\hline Total exposure, patient-years ) & 7769.0 & 1907.0 \\
Min-max exposure (days) & $1-1526$ & $16-1464$ \\
Death, $\mathrm{n}(\%)$ & $7(0.2)$ & $4(0.4)$ \\
AE's by EAIR: AE per 100 Pt-years $(95 \% \mathrm{Cl})$ & & \\
$\quad$ Any AE & $196.9(190.3,203.6)$ & $173.7(162.5,185.5)$ \\
$\quad$ Any serious AE & $7.2(6.6,7.8)$ & $8.5(7.2,10.0)$ \\
Frequent AEs ${ }^{1}$ & & \\
$\quad$ Nasopharyngitis & $18.2(17.1,19.3)$ & $13.7(12.0,15.7)$ \\
$\quad$ Headache & $6.3(5.7,6.9)$ & $4.8(3.9,5.9)$ \\
$\quad$ Upper respiratory tract infections & $6.2(5.6,6.8)$ & $11.2(9.6,12.9)$ \\
$\quad$ Arthralgia & $5.1(4.6,5.6)$ & $4.3(3.4,5.3)$ \\
AEs of special interest & & \\
$\quad$ Candida infections & $2.1(1.8,2.4)$ & $2.3(1.6,3.1)$ \\
$\quad$ Serious infections & $1.4(1.2,1.7)$ & $1.8(1.3,2.5)$ \\
Inflammatory Bowel Disease & $0.3(0.2,0.4)$ & $0.5(0.2,0.9)$ \\
Crohn's disease & $0.1(0.0,0.1)$ & 0 \\
Ulcerative colitis & $0.2(0.1,0.3)$ & $0.1(0.0,0.4)$ \\
MACE & $0.3(0.2,0.5)$ & $0.3(0.1,0.6)$ \\
Neutropenia & $0.4(0.3,0.5)$ & $0.7(0.4,1.2)$ \\
\hline
\end{tabular}

${ }^{1}$ Adverse events in the secukinumab group that occurred with an IR $>5.0$ during the entire safety period in either of the spooled groups; AE, adverse event; EAIR, exposure adjusted incidence rate per 100 patient-years; MACE, major adverse cardiac event; N, number of patients in the analysis.

Conclusions: The safety profile of secukinumab was similar for PsO and PsA patients supporting its long-term use in these chronic conditions. Secukinumab long-term exposure safety data is consistent with that previously reported with shorter-term exposure, including being well tolerated, and without any new safety signals identified.

References:

[1] Van de Kerkhof PC, et al. J Am Acad Dermatol 2016;75:83-98.

[2] Mease PJ, et al. Arthritis Rheumatol 2015; 67:A2886.

Disclosure of Interest: P. Mease Grant/research support from: AbbVie, Amgen, Biogen Idec, BMS, Celgene, Crescendo, Janssen, Lilly, Merck, Novartis, Pfizer, and UCB, Consultant for: AbbVie, Amgen, Biogen Idec, BMS, Celgene, Covagen, Crescendo, Janssen, Lilly, Merck, Novartis, Pfizer, UCB, Speakers bureau: AbbVie, Amgen, Biogen Idec, BMS, Crescendo, Janssen, Lilly, Pfizer, and UCB, I. McInnes Grant/research support from: AbbVie, Amgen, BMS, Celgene, Janssen, Lilly, Novartis, Pfizer, and UCB, Consultant for: AbbVie, Amgen, BMS, Celgene, Janssen, Lilly, Novartis, Pfizer, and UCB, Speakers bureau: AbbVie, Amgen, BMS, Celgene, Janssen, Lilly, Novartis, Pfizer, and UCB, K. Reich Grant/research support from: AbbVie, Amgen, Biogen, Boehringer Ingelheim Pharma, Celgene, Centocor, Covagen, Forward Pharma, GlaxoSmithKline, Janssen-Cliag, Leo, Lilly, Medac, Merck Sharp and Dohme Corp., Novartis, Ocean Pharma, Pfizer, Regeneron, Takeda, UCB Pharma, Xenoport, Speakers bureau: AbbVie, Amgen, Biogen, Boehringer Ingelheim Pharma, Celgene, Centocor, Covagen, Forward Pharma, GlaxoSmithKline, Janssen-Cliag, Leo, Lilly, Medac, Merck Sharp and Dohme Corp., Novartis, Ocean Pharma, Pfizer, Regeneron, Takeda, UCB Pharma, Xenoport, P. Nash Grant/research support from: AbbVie, Amgen, BMS, Celgene, Eli Lilly, Hospira, MSD, Pfizer, Janssen, UCB, Novartis, Roche; Consultancy fees: AbbVie, Amgen, BMS, Celgene, Eli Lilly, Hospira, MSD, Pfizer, Janssen, UCB, Novartis, Roche, Speakers bureau: AbbVie, Amgen, BMS, Celgene, Eli Lilly, Hospira, MSD, Pfizer, Janssen, UCB, Novartis, Roche, M. Andersson Employee of: Novartis, K. Abrams Shareholder of: Novartis, Employee of: Novartis, L. Pricorp Shareholder of: Novartis, Employee of: Novartis, T. Fox Shareholder of: Novartis, Employee of: Novartis

DOI: 10.1136/annrheumdis-2017-eular.4991

\section{FRI0512 APREMILAST, AN ORAL PHOSPHODIESTERASE 4 INHIBITOR, IS ASSOCIATED WITH LONG-TERM (156-WEEK) IMPROVEMENTS IN BASDAI IN PSORIATIC ARTHRITIS PATIENTS: POOLED RESULTS FROM 3 PHASE III, RANDOMIZED, CONTROLLED TRIALS}

P.J. Mease ${ }^{1}$, H. Marzo-Ortega ${ }^{2}$, A. Poder ${ }^{3}$, F. Van den Bosch ${ }^{4}$, J. Wollenhaupt ${ }^{5}$, E. Lespessailles ${ }^{6}$, M. Mcllraith ${ }^{7}$, L. Teng ${ }^{7}$, S. Hall ${ }^{8} .{ }^{1}$ Swedish Medical Center and University of Washington School of Medicine, Seattle, United States: ${ }^{2}$ NIHR Leeds Musculoskeletal Biomedical Research Unit, Leeds Teaching Hospitals and University of Leeds, Leeds, United Kingdom; ${ }^{3}$ Clinical Research Centre Ltd, Tartu, Estonia; ${ }^{4}$ UZ Gent, Gent, Belgium; ${ }^{5}$ Schön Klinik Hamburg Eilbek, Hamburg, Germany; ${ }^{6}$ University of Orléans, Orléans, France; ${ }^{7}$ Celgene Corporation, Summit, United States; ${ }^{8}$ Monash University, CabriniHealth, Melbourne, Australia

Background: In PALACE psoriatic arthritis (PSA) studies, the Bath Ankylosing Spondylitis Disease Activity Index score (BASDAl) was used as an exploratory measure in a subset of patients (pts) considered by investigators to have axial involvement, although PSA spondylitis was not confirmed by imaging.

Objectives: Report the impact of apremilast $30 \mathrm{mg}$ BID (APR) treatment on BASDAl over 156 wks using pooled PALACE 1-3 data of pts with active PsA despite prior conventional DMARDs and/or biologics. 